\title{
Acute myocardial infarction as the first presentation of thyrotoxicosis in a 31-year old woman - case report
}

\author{
Krzysztof C Lewandowski ${ }^{1}$, Tomasz Rechciński ${ }^{2}$, Maria Krzemińska-Pakuła ${ }^{2 \dagger}$, Andrzej Lewiński $^{{ }^{*+}}$
}

\begin{abstract}
A 31-year old woman, previously fit \& well was admitted with pressing retrosternal chest pain and palpitations of sudden onset. Her body weight was normal (BMl $20.5 \mathrm{~kg} / \mathrm{m}^{2}$ ) and there was no significant family history of cardiac disease. She smoked, however, about 15 cigarettes a day and she had been taking combined oral contraceptive pill (Cilest ${ }^{\oplus}$ ) for about three years. On admission she appeared sweaty and in pain, blood pressure 130/70 mmHg, heart rate about 110/min, mild lid-lag sign. Heart sounds were normal and chest was clear. ECG revealed 2-3 mm ST segment elevations in II, III, aVF as well as V2 to V5. Troponin I was raised and she was qualified to an emergency coronary angiography. This revealed a massive spasm of left anterior descending (LAD) coronary artery that responded to intracoronary glyceryl trinitrite administration, however, with the presence of critical narrowing of the LAD apical segment with possible superimposed thrombus. Cardiac ultrasound revealed akinesis of $1 / 2$ of apical area consistent with myocardial infarction
\end{abstract}

Treatment and progress: She was started on Aspirin, Simvastatin, and Diltiazem, but continued to have persistent tachycardia and tremor. Thyroid function tests were ordered and showed thyrotoxicosis [free T4-46.9 pmol/I (ref. range 9-25), free T3-11.9 pmol// (2-5), TSH - $0.02 \mathrm{mlU} / \mathrm{l}(0.27-4.2)]$. She was referred for an endocrine opinion and started on Thiamazole. Other investigations revealed elevated anti-TPO and anti-TSH receptor antibodies consistent with Graves' disease. Thrombophilia screen was negative. She had remained euthyroid on a "block \& replace" regimen (Thiamazole plus L-Thyroxine) that was discontinued after 18 months. She denies any anginal symptoms, but continues to smoke against medical advice.

Conclusions: Our case highlights the possibility of development of an acute myocardial infarction in a young subject with thyrotoxicosis. We speculate that patient's smoking habit combined with subtle thyrotoxicosis-induced prothrombotic state and/or coronary-artery spasm had lead to the above-mentioned acute coronary event.

\section{Background}

Acute myocardial infarction (MI) can occur in young subjects, and typical precipitating factors may include hyperlipidaemias, hypercoagulable states, cocaine abuse and other factors. According to the US data about $80 \%$ of young subjects are overweight or obese and at least one the classical cardiovascular risk factors is present in about $96 \%$ of cases [1]. Acute MI is, however, still relatively rare in young women and in a case series of 165 patients admitted with acute MI aged below 45 with

\footnotetext{
* Correspondence: alewin@csk.umed.lodz.pl

† Contributed equally

1 Department of Endocrinology \& Metabolic Diseases, The Medical University of Lodz, "Polish Mother" Memorial Research Institute, Rzgowska 281/89, 93-
} 338 Lodz, Poland

(c) 2010 Lewandowski et al; licensee BioMed Central Ltd. This is an Open Access article distributed under the terms of the Creative Commons Attribution License (http://creativecommons.org/licenses/by/2.0), which permits unrestricted use, distribution, and reproduction in any medium, provided the original work is properly cited. (average age $41.3 \pm 4.6$ years, range $22-45$ years) women constituted only $16 \%$ of cases [1]. We present the case where acute MI was an initial presentation of thyrotoxicosis in a young women of 31 years of age who had been entirely fit \& well prior to this acute coronary event.

\section{Case Presentation}

A 31-year old woman, previously fit \& well was admitted with a history of sudden onset of pressing retrosternal pain and palpitations. Her body weight was normal (BMI $20.5 \mathrm{~kg} / \mathrm{m}^{2}$ ). She had no significant family history of ischaemic heart disease and had one healthy child of 5 years of age. She smoked, however, about 15 cigarettes a day and she had been taking Cilest ${ }^{\circ}$ i.e. a 
combined oral contraceptive pill, that contains $0.035 \mathrm{mg}$ of Ethynylestradiol and $0.250 \mathrm{mg}$ Norgestimate, for about three years prior to her admission. On examination she was sweaty and in pain, blood pressure 130/70 $\mathrm{mmHg}$, heart rate about $110 / \mathrm{min}$, mild lid-lag sign. Heart sounds were normal and chest was clear. ECG (see Figure 1) revealed 2-3 mm ST segment elevations in II, III, aVF as well as V2 to V5. Initial laboratory tests revealed normal electrolytes, and clotting screen, normal Full Blood Count and surprisingly low concentrations of plasma lipids (total cholesterol - $117 \mathrm{mg} / \mathrm{dl}$, triglycerides - $93 \mathrm{mg} / \mathrm{dl}$, LDL-cholesterol - $61 \mathrm{mg} / \mathrm{dl}$, HDL-cholesterol - $37.8 \mathrm{mg} / \mathrm{dl}$ ). Troponin I levels were, however, markedly raised $(12.2 \mu \mathrm{g} / \mathrm{l})$ and so she was qualified for an emergency coronary angiography (presented in Figure 2). This revealed a massive spasm of left anterior descending (LAD) coronary artery that responded to intracoronary glyceryl trinitrite administration, however, with the presence of critical narrowing of the LAD apical segment with possible superimposed thrombus. Cardiac ultrasound revealed akinesis of $1 / 2$ of apical area with hypokinesis of adjacent segments, ejection fraction $38 \%$ - Figure 3 . The titre of antinuclear antibodies was normal.

She was started on standard medication used in patients after myocardial infarction (Aspirin, Clopidogrel, Heparin, Simvastatin, Diltiazem), but despite this she was noted to have persistent tachycardia about 100-

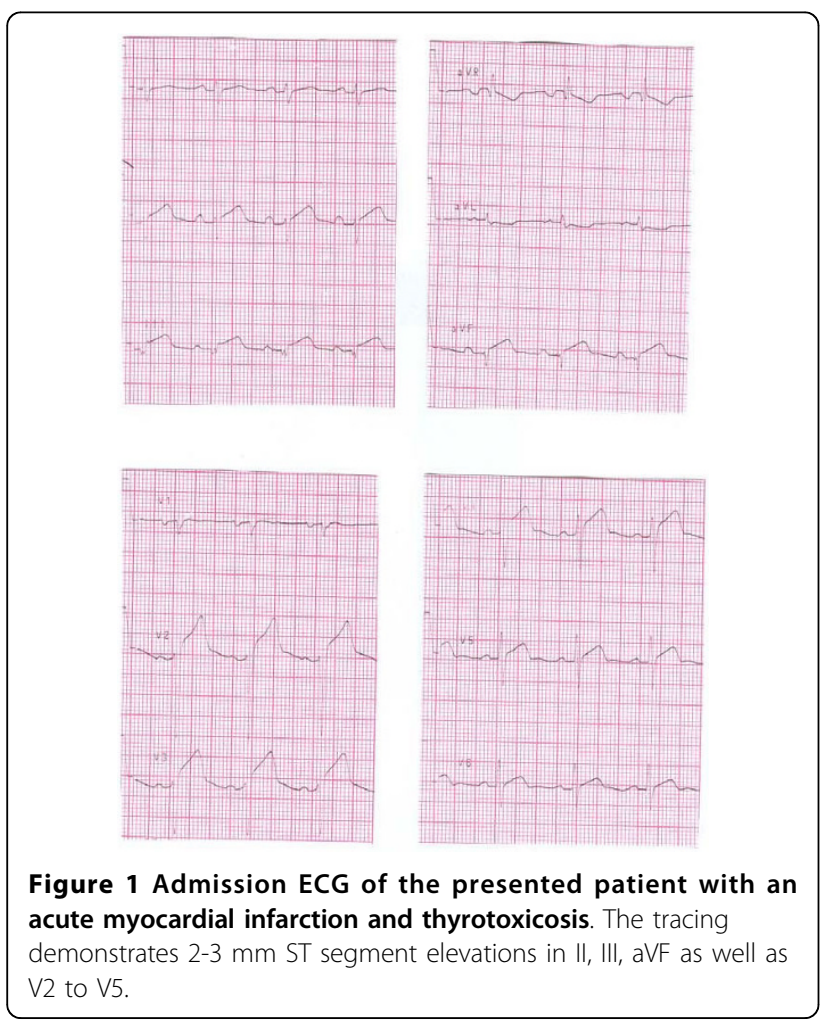

110 beats/minute and tremor. On the strength of that thyroid function tests were requested and revealed thyrotoxicosis (see Table 1). She was started on Thiamazole (Metizol@) $20 \mathrm{mg}$ b.d.and referred for an endocrine opinion.

In the Endocrine Clinic she was still hyperthyroid with a thyroid bruit and was clinically diagnosed to have Graves'disease. Thyroid ultrasound scan showed no focal lesions. She was subsequently found to have raised both anti-TSH receptor and anti-thyroid peroxidase antibodies that was confirmed autoimmune thyrotoxicosis (Table 2). Further autoimmune screen (also Table 2) revealed no evidence of thrombophilia. Following normalisation of free T4 and free T3 she was stabilized on a "block \& replace regimen" (Thiamazole (Metizol@) plus L-thyroxine) that was continued for about 18 months. She currently remains euthyroid without medication [TSH - 1.39 $\mathrm{mIU} / \mathrm{l}$ (Ref. 0.27-4.2)], but despite several warnings continues to smoke about 10 cigarettes a day. Following successful treatment of thyrotoxicosis her lipid profile showed significant rise in cholesterol levels in comparison to the thyrotoxic phase suggestive of occult dyslipidaemia previously masked by thyrotoxicosis (total cholesterol - $227 \mathrm{mg} / \mathrm{dl}$, LDL-cholesterol - $164 \mathrm{mg} / \mathrm{dl}$, HDL-cholesterol - $41 \mathrm{mg} / \mathrm{dl}$, triglycerides - $109 \mathrm{mg} / \mathrm{dl}$ ).

\section{Discussion}

Both hyper- and hypothyroidism are known to be associated with coagulation abnormalities. In case of hypothyrodism the data are somehow conflicting and

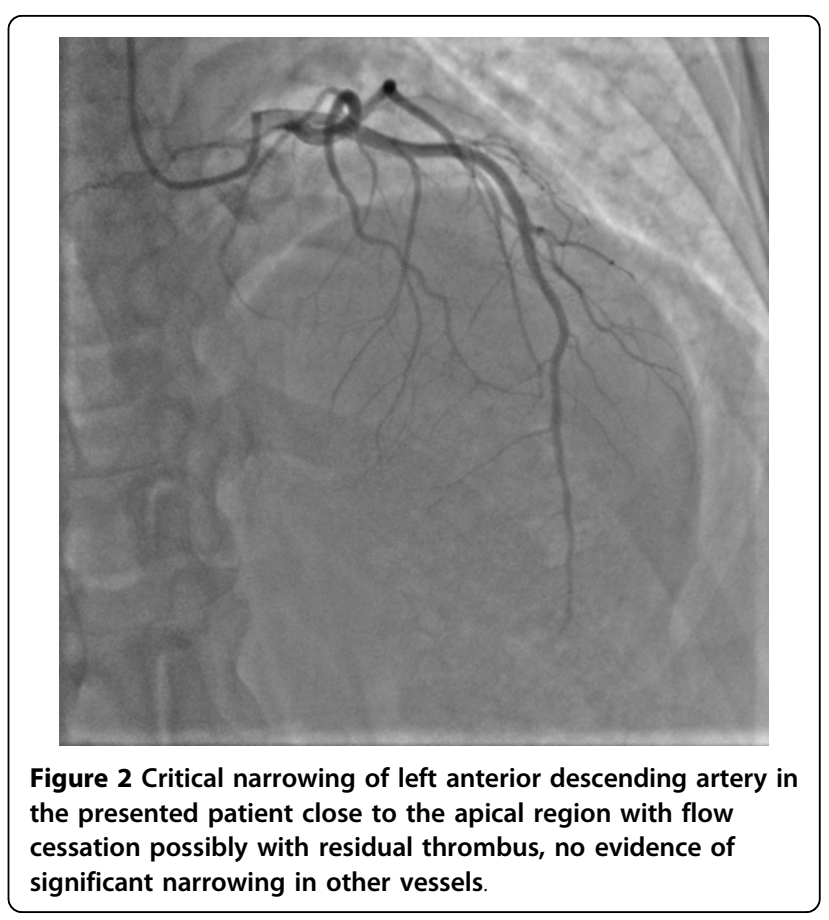




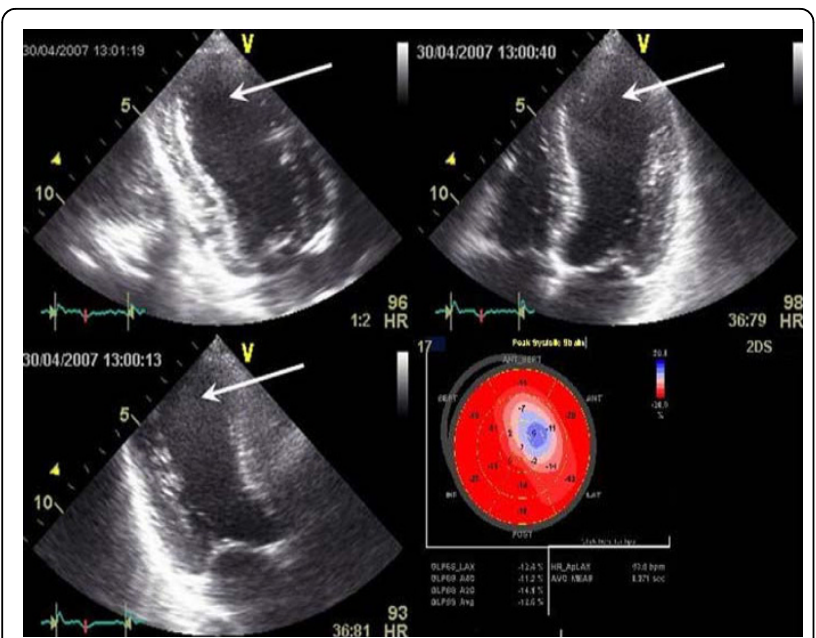

Figure 3 Echocardiographic image showing left ventricular wall motion abnormalities of the apex in systole (arrows): apical two chamber view (left upper panel), four chamber view (right upper panel) and three chamber view (left lower panel). Matching bulls eye display of left ventricular segments strain quantitative analysis (right lower panel). Reduced myocardial contraction within the region of myocardial infarction is clearly visible (blue and pink colour).

the type of coagulation abnormalities may be, at least in part, related to the degree hypothyroidism [2]. In brief, milder forms of hypothyroidism may present with abnormalities resembling von Willenbrand's disease [3], i.e. decreased platelet adhesives, abnormal bleeding times, decreased levels of factors VIII, IX, XI and XII and a state with low von Willebrandt factor (vWF) activity [3], while severe hypothyroidism may result in a hypocoagulable state as shown by increases in platelet and factor VII as well as by decreases in fibrinolytic activity [4]. On the other hand there is quite consistent evidence that thyrotoxicosis is directly associated with the presence of a prothrombotic state. Horne et al. [5] demonstrated higher concentrations of prothrombin fragment $1+2$, fibrynogen, factor VIII, antithrombin, tissue plasminogen activator antigen (tPA), plasminogen activator inhibitor 1 (PAI-1), PAI-1/tPA ratio and Creactive protein in subjects with a history of cured thyroid cancer receiving standard TSH-suppressive L-thyroxine therapy in comparison to concentrations of the above parameters measured in the same subjects in a hypothyroid phase prior to radioiodine whole-body scanning procedure. Interestingly, anticoagulative factors, namely protein $\mathrm{C}$ and plasmin-antiplasmin complexes were also significantly lower during the hyperthyroid period. Squizzato et al. [6] described increased incidence of acute cerebral ischaemia in subjects with hyperthyroidism that was independent of thyrotoxic atrial fibrillation and cardioembolic stroke. More recently Homoncik et al. [7] have reported raised concentrations of vWF and increased baseline platelet plug formation in patients with thyrotoxicosis. These abnormalities were corrected by treatment of thyrotoxicosis with thiamazole. Also subjects with L-thyroxine-induced thyrotropin suppression as part of treatment of benign thyroid nodules were found to have a pro-coagulable profile [8]. In contrast, subjects with hypothyroidism had lower concentrations vWF antigen and factor VIII together with longer partial thromboplastin time (APTT) that was corrected by treatment with L-thyroxine. This might indicate the potential for increased bleeding tendency in subjects with hypothyroidism. We speculate whether the above mentioned abnormalities may contribute to an increased prevalence of menorrhagia typically observed in subjects with hypothyroidism.

Furthermore, long-term follow-up studies have revealed increased mortality from cardiovascular and cerebrovascular disease in those with past history of overt hyperthyroidism [9] as well as in those with subclinical hyperthyroidism [10]. In another study an elevated serum fT3 concentration was associated with a 2.6-fold greater likelihood of the presence of a coronary event [11].

Our subject was a smoker, and so despite a normal BMI she had a clear risk factor for $\mathrm{CV}$ disease i.e. like $96 \%$ of young subjects presenting with MI, as described, by Zarich et al. [1]. Though connective tissue disease [12] or factor V Leyden mutations and other thrombophilias have been linked with acute thrombotic events [13], we did not find evidence of thrombophilia or connective tissue disease in our subject. Her lipid profile with low cholesterol levels is likely to be a direct result of thyrotoxicosis, but one should note that satisfactory lipid profiles are not uncommon among young subjects with MI. For instance, Zarich et al. [1] reported LDL cholesterol levels below $100 \mathrm{mg} / \mathrm{dl}$ in $32 \%$ of young subjects with acute MI, while Akosah et al. [14] report LDL

Table 1 Selected biochemical results and thyroid function test of the presented 31-year old female patient with an acute myocardial infarction

\begin{tabular}{|c|c|c|c|c|c|c|c|}
\hline \multirow[b]{2}{*}{$\begin{array}{c}\text { Glucose } \\
\text { (mg/dl) } \\
\text { Ref: } \\
60-100\end{array}$} & \multirow[b]{2}{*}{$\begin{array}{c}\text { Urea } \\
\text { (mg/dl) } \\
\text { Ref: } \\
20-40\end{array}$} & \multirow[b]{2}{*}{$\begin{array}{c}\text { Creatinine } \\
\text { (mg/dl) } \\
\text { Ref: } \\
0.5-1.35\end{array}$} & \multirow[b]{2}{*}{$\begin{array}{l}\text { Total cholesterol } \\
(\mathrm{mg} / \mathrm{dl})\end{array}$} & \multirow[b]{2}{*}{$\begin{array}{l}\text { Triglycerides } \\
\text { (mg/dl) }\end{array}$} & \multicolumn{2}{|c|}{ Thyroid hormones } & \multirow[b]{2}{*}{$\begin{array}{c}\text { TSH } \\
\text { (mlU/l) } \\
\text { Ref: } \\
0.27-4.2 \\
\end{array}$} \\
\hline & & & & & $\begin{array}{c}\text { Free T4 (pmol/l) } \\
\text { Ref: } \\
9-25\end{array}$ & $\begin{array}{c}\text { Free T3 } \\
\text { (pmol/l) } \\
\text { Ref: } \\
2-5\end{array}$ & \\
\hline 94 & 21 & 0.42 & 117 & 93 & 46.9 & 11.9 & 0.02 \\
\hline
\end{tabular}


Table 2 Results of auto-immune screening of the presented 31-year old patient with a history of an acute myocardial infarction and thyrotoxicosis obtained in the Endocrine Clinic.

\begin{tabular}{|c|c|c|c|c|c|}
\hline $\begin{array}{c}\text { Thyroid peroxidase } \\
\text { antibodies (aTPO) }(\mathrm{IU} / \mathrm{ml}) \\
{[\text { Ref.<60] }}\end{array}$ & $\begin{array}{c}\text { Anti-TSH receptor } \\
\text { antibodies (IU/I) } \\
{[\text { Ref. }<1.8]}\end{array}$ & $\begin{array}{l}\text { Lupus anticoagulant (ratio) } \\
\text { [Ref. ratio }<1.3]\end{array}$ & $\begin{array}{c}\begin{array}{c}\text { Factor V } \\
(\%)\end{array} \\
\text { [Ref. } 70-120]\end{array}$ & $\begin{array}{c}\begin{array}{c}\text { Protein S } \\
(\%)\end{array} \\
\text { [Ref. } 70-125]\end{array}$ & $\begin{array}{c}\text { Protein S } \\
\text { (\%) } \\
\text { [Ref: } 70-140]\end{array}$ \\
\hline 607 & 22.8 & 1.05 & 77.1 & 71.3 & 104 \\
\hline
\end{tabular}

cholesterol levels below $130 \mathrm{mg} / \mathrm{dl}$ in more than $50 \%$ young adults with premature heart disease. Though our subject did use an oral contraceptive pill, we note that in contrast to increased risk of deep venous thrombosis, acute $\mathrm{MI}$ is actually very rare among the users of oral contraceptive pill and no evidence of thrombophilia [15]. In another recent study there was no increase in the risk of acute MI among 48321 Swedish women aged 30-49 years who used oral contraceptive pill [16]. Coronary artery spasm, also described in our patient, might be another factor contributing the the development of an acute myocardial infarction. There are also reports of severe coronary artery spasm leading to a myocardial infarction in young subjects with thyrotoxicosis, however, without classical cardiovascular disease risk factors [17]. Furthermore coronary artery spasm seems to be more common in smokers [18], while our patient smoked about 15 cigarettes a day.

Administration of iodine contrast during coronarography was also unlikely to have any adverse effects on thyroid function as iodine contrasts typically suppress thyroid hormone release in the short-term (the WolffChaikoff effect), the phenomenon that is utilized in rapid preparation for thyroid surgery, or in the treatment of thyrotoxic storm $[19,20]$. Only prolonged administration of iodine compounds may contribute to the development of thyrotoxicosis through the so called WolffChaikoff escape phenomenon [20].

\section{Conclusions}

Our case highlights the possibility that thyrotoxicosis may facilitate development of an acute myocardial infarction even in a young person without previous history of thrombosis, vasculitis or heart disease. In our opinion cigarette smoking combined with a thyrotoxicosis-induced prothrombotic state was enough to tip the balance towards development of acute coronary thrombosis and subsequent acute myocardial infarction even in such a young and not-obese female subject. Our case therefore highlights the need for awareness of the possibility of such serious complication even among young subjects with thyrotoxicosis.

\section{Consent}

Written informed consent was obtained from the patient for publication of this case report and any accompanying images. A copy of the written consent is available for review by the Editor-in-Chief of this journal.

\section{Author details}

'Department of Endocrinology \& Metabolic Diseases, The Medical University of Lodz, "Polish Mother" Memorial Research Institute, Rzgowska 281/89, 93338 Lodz, Poland. ${ }^{2}$ Ind Chair \& Department of Cardiology, The Medical University of Lodz, The Bieganski Hospital, Kniaziewicza 1/5, 91-347 Lodz, Poland.

\section{Authors' contributions}

$\mathrm{KCL}(\mathrm{PhD} M \mathrm{MRCP})(\mathrm{UK})$ : Principal management of the patient in the Endocrine Clinic, writing of the paper.

TR (PhD): Principal management of the patient in the Department of Cardiology, writing of the paper

MK-P (PhD Professor of Medicine \& Cardiology): Senior supervision of the management of the patient in the Department of Cardiology (including cardiac ultrasound), writing of the paper.

AL (PhD Professor of Medicine \& Endocrinology): Senior supervision of endocrine management, writing of the paper.

All authors have read and approved the final manuscript.

\section{Competing interests}

The authors declare that they have no competing interests.

Received: 12 January 2010

Accepted: 8 February 2010 Published: 8 February 2010

\section{References}

1. Zarich S, Luciano C, Hulford J, Abullah A: Prevalence of metabolic syndrome in young patients with acute Ml: does the Framingham Risk Score underestimate cardiovascular risk in this population?. Diab Vasc Dis Res 2006, 3:103-107.

2. Gullu S, Sav H, Kamel N: Effects of levothyroxine treatment on biochemical and hemostasis parameters in patients with hypothyroidism. Eur J Endocrinol 2005, 152:355-361.

3. Attivissimo LA, Lichtman SM, Klein I: Acquired von Willebrand's syndrome causing a hemorrhagic diathesis in a patient with hypothyroidism. Thyroid 1995, 5:399-401.

4. Muller B, Tsakiris D, Roth C, Guglielmetti M, Staub J, Marbet M: Haemeostatic profile in hypothyroidism as potential risk factor for vascular or thrombotic disease. Eur J Clin Invest 2001, 31:131-137.

5. Horne McD, Singh KK, Rosenfeld KG, Wesley R, Skarulis MC, Merryman PK, Cullinane A, Costello R, Patterson A, Eggerman T, Bernstein DM, Pucino F, Csako G: Is Thyroid Hormone Suppression Therapy Prothrombotic?. J Clin Endocrinol Metab 2004, 89:4469-4473.

6. Squizzato A, Gerdes VE, Branjes DP, Buller HR, Stam J: Thyroid diseases and cerebrovascular disease. Stroke 2005, 36:2302-2310.

7. Homoncik M, Gessl A, Ferlitsch A, Jilma B, Vierhapper H: Altered platelet plug formation in hyperthyroidism and hypothyroidism. J Clin Endocrinol Metab 2007, 92:3006-3012.

8. Demir T, Akinci B, Comlekci A, Karaoglu O, Ozcan MA, Yener S, Yuksel F, Secil M, Yesil S: Levothyroxine suppression treatment for benign thyroid nodules alters coagulation. Clin Endocrinol (Oxf) 2009, 71:446-450.

9. Franklyn JA, Maisonneuve P, Sheppard MC, Betteridge J, Boyle P: Mortality after treatment of hyperthyroidism with radioactive iodine. $N$ Engl J Med 1998, 338:712-718.

10. Parle JV, Maisonneuve P, Sheppard MC, Boyle P, Franklyn JA: Predictors of all cause and cardiovascular mortality in elderly people from one low 
serum thyrotropin result: a 10-year cohort study. Lancet 2001, 358:861-865.

11. Peters A, Ehlers M, Blank B, Exler D, Falk C, Kohlmann T, FruehwaldSchultes B, Wellhoener P, Kerner W, Fehm HL: Excess triiodothyronine as a risk factor of coronary events. Arch Intern Med 2000, 160:1993-1999.

12. Karrar A, Sequeira W, Block JA: Coronary artery disease in systemic lupus erythematosus: A review of the literature. Semin Arthritis Rheum 2001, 30:436-443.

13. Dacosta A, Tardy-Poncet B, Isaaz K, Cerisier A, Mismetti P, Simitsidis S, Reynaud J, Tardy B, Piot M, Decousus H, Guyotat D: Prevalence of factor V Leiden (APCR) and other inherited thrombophilias in young patients with myocardial infarction and normal coronary arteries. Heart 1998, 80:338-340.

14. Akosah KO, Gower E, Groon L, Rooney BL, Schaper A: Mild hypercholesterolaemia and premature heart disease: Do the national criteria underestimate disease risk?. J Am Coll Cardiol 2000, 35:1178-1184.

15. Cole JA, Norman H, Doherty M, Walker AM: Venous thromboembolism, myocardial infarction, and stroke among transdermal contraceptive system users. Obstet Gynecol 2007, 109:339-346.

16. Margolis KL, Adami HO, Luo J, Ye W, Weiderpass E: A prospective study of oral contraceptive use and risk of myocardial infarction among Swedish women. Fertil Steril 2007, 88:310-316.

17. Grąbczewska Z, Białoszyński T, Kubica J: Acute myocardial infarction in a patient with iatrogenic thyrotoxicosis - a case report. Kardiol Pol 2007, 65:280-282.

18. Ashikaga T, Nishizaki M, Fujii H, Niki S, Maeda S, Yamawake N, Kishi Y, Isobe M: Examination of the microcirculation damage in smokers versus nonsmokers with vasospastic angina pectoris. Am J Cardiol 2007, 100:962-964.

19. Panzer C, Beazley R, Braverman L: Rapid preoperative preparation for severe hyperthyroid Graves' disease. J Clin Endocrinol Metab 2004, 89:2142-2144.

20. Braga M, Cooper DS: Clinical review 129: Oral cholecystographic agents and the thyroid. J Clin Endocrinol Metab 2001, 86:1853-1860.

doi:10.1186/1756-6614-3-1

Cite this article as: Lewandowski et al: Acute myocardial infarction as the first presentation of thyrotoxicosis in a 31-year old woman - case report. Thyroid Research 2010 3:1.

\section{Submit your next manuscript to BioMed Central and take full advantage of:}

- Convenient online submission

- Thorough peer review

- No space constraints or color figure charges

- Immediate publication on acceptance

- Inclusion in PubMed, CAS, Scopus and Google Scholar

- Research which is freely available for redistribution

Submit your manuscript at www.biomedcentral.com/submit 